\author{
Barbara Wieliczko \\ Instytut Ekonomiki Rolnictwa i Gospodarki Żywnościowej-PIB \\ Michat Soliwoda \\ Instytut Ekonomiki Rolnictwa i Gospodarki Żywnościowej-PIB \\ Jacek Kulawik \\ Instytut Ekonomiki Rolnictwa i Gospodarki Żywnościowej-PIB
}

\title{
Inżynieria finansowa i instrumenty finansowe a problemy budżetowe UE
}

\section{FINANCIAL ENGINEERING AND FINANCIAL INSTRUMENTS VS. EU BUDGET PROBLEMS}

Obecnie intensywnie poszukiwane sq możliwości efektywniejszego wykorzystania dysponowanych dochodów fiskalnych przez UE. Duże nadzieje w tym kontekście wiqże się z inżynieria finansowa $i$ instrumentami finansowymi. Podstawowym celem artykulu jest przyblizienie istoty, korzyści i zagrożeń oraz obszarów zastosowań inżynierii finansowej oraz instrumentów finansowych. Opracowanie ma charakter studium przegladowego. Została wykorzystana metoda dokumentacyjna i studiów literaturowych. Rozlegty interwencjonizm finansowy i kredytowy w dluższym okresie może jednakże doprowadzić do ostabienia bodźców do wzrostu efektywności i produktywności. Szczególne niebezpieczeństwo pojawia się wtedy, gdy interwencja publiczna zdominowana jest przez dotacje i subwencje. W przypadku UE poleganie na wsparciu dotacyjnym dotyczy głównie WPR oraz polityki spójności, które obecnie stanowiq 70\% wydatków wspólnoty. W tym kontekście instrumenty finansowe, chociaż nie pozbawione wad, powinny $w$ coraz większym stopniu stawać się substytutami subsydiów. Nie będzie to jednak łatwy i szybki proces, co znajdzie wyraz w ostrości negocjacji budżetu Wspólnoty na lata 2020+ oraz w jego finalnym kształcie.

Słowa kluczowe: instrumenty finansowe, polityka spójności, dotacje, budżet UE, sektor MŚP.

\section{Wprowadzenie}

Opuszczenie przez Wielką Brytanię struktur Unii Europejskiej (UE), zaplanowane na 29.03.2019, może spowodować spadek dochodów budżetowych UE najpierw o 8-9, a później o 10-12 mld euro rocznie. Równolegle zdecydowana większość krajów członkowskich musi zwiększyć swój wkład w finansowanie NATO, by Amerykanie nadal byli zainteresowani tym sojuszem. Wciąż nie rozwiązany do końca kryzys migracyjny wymagać będzie znacznych środków na wsparcie Turcji oraz ewentualnie Libii i może też innych krajów, by potencjalni migranci pozostali w swoich dotychczasowych ojczyznach. Część krajów UE chce ponadto trwale osiagać nadwyżki budżetowe, by móc amortyzować przyszłe szoki makroekonomiczne. Jak widać, zbilansowanie budżetu UE już w tej perspektywie może być dużym problemem. Skonstruowanie kolejnej perspek- 
tywy obecnie rysuje się jeszcze jako poważniejsze wyzwanie. Nie dziwi zatem, że intensywnie poszukuje się możliwości efektywniejszego wykorzystania dysponowanych dochodów fiskalnych. Duże nadzieje w tym kontekście wiąże się z inżynierią finansową i instrumentami finansowymi. Podstawowym celem artykułu jest przybliżenie istoty, korzyści i zagrożeń oraz obszarów zastosowań inżynierii finansowej oraz instrumentów finansowych.

\section{Kształt budżetu Wspólnoty po 2020 roku}

Trwają prace nad budżetem Wspólnoty po 2020 roku ${ }^{1}$. Budżet ma zostać przyjęty w grudniu 2018 roku. Motywem przewodnim propozycji budżetowej KE na okres 20212027 jest sprawienie, aby UE była gotowa silnego do roli globalnego aktora. Sam tytuł komunikatu KE brzmi „Nowoczesny budżet dla Unii, która chroni, wspiera i broni”2 wskazuje na priorytety UE w kolejnych latach. Struktura nowego budżetu ma odzwierciedlać dążenie do tego, aby Unia była „bardziej zjednoczona, silniejsza i bardziej demokratyczna"3. KE oparła swój projekt budżetu na następujących zasadach ${ }^{4}$ :

- Większy nacisk na europejską wartość dodaną.

- Lepiej funkcjonujący i bardziej przejrzysty budżet.

- Mniej biurokracji dla beneficjentów.

- Bardziej elastyczny, lepiej funkcjonujący budżet.

- $\quad$ Budżet, który przynosi efekty.

Komisja proponuje, aby wysokość zobowiązań w wieloletnich ramach finansowych na lata 2021-2027 wyniosła 1279 mld euro. Stanowi to równowartość 1,114 \% dochodu narodowego brutto UE-27. Propozycja KE przewiduje znaczne zwiększenie wydatków na następujące priorytety UE:

- Badania, innowacje, technologie cyfrowe - mnożnik wzrostu wydatków 1,6;

- Młodzież - 2,2;

- $\quad$ LIFE klimat i środowisko - 1,7;

- $\quad$ Migracja i granice - 2,6;

- Bezpieczeństwo - 2,8;

- Działania zewnętrzne - 1,3:

- Uwzględnianie kwestii klimatu przyczynianie się do celów klimatycznych - 1,6.

\footnotetext{
${ }^{1}$ Warto podkreślić, że tzw. biała księga (White Paper), będącą rezultatem wspólnej pracy KE, PE i RE (opublikowana 1 marca 2017 r.) zawiera aż 5 scenariuszy rozwoju UE do 2025 roku: (1) Kontynuacji, (2) Mniej wspólnych działań, (3) Niektóre państwa robią więcej, (4) Radykalna zmiana koncepcji, (5) Znacznie więcej wspólnych działań. Co więcej, każdy scenariusz składa się z trzech elementów: ogólne tendencje i wielkość (budżetu), wydatki (WPR; spójność gospodarcza, społeczna i terytorialna; nowe priorytety; reformy strukturalne), dochody budżetu wspólnotowego. Por. European Commission, 2016, European Structural and Investment Funds and European Fund for Strategic Investments complementarities Ensuring Coordination, Synergies And Complementarity February 2016.

http://ec.europa.eu/regional_policy/sources/thefunds/fin_inst/pdf/efsi_esif_compl_en.pdf, dostęp z dnia 1.07.2017.

${ }^{2}$ Komisja Europejska, Komunikat Komisji i Parlamentu Europejskiego, Rady Europejskiej, Rady, Europejskiego Komitetu Ekonomicznospołecznego i Komitetu Regionów , Nowoczesny budżet dla Unii, która chroni, wspiera i broni. Wieloletnie ramy finansowe na lata 2021-2027, COM(2018)321, 2018.

${ }^{3}$ Ibidem.

${ }^{4}$ Ibidem.
} 
W przypadku wspólnej polityki rolnej przewidziano budżet wynoszący $365 \mathrm{mld}$ euro (w cenach bieżących), z czego na II filar WPR zaplanowano jedynie ok. 21,6\% tej kwoty. Budżet WPR w tej wysokości oznacza spadek wydatków o 3\% w stosunku do budżetu 2014-2020 (tab. 1), przy czym budżet Europejskiego Funduszu Rolnego Gwarancji, czyli I filara WPR ma wzrosnąc o 2\%, zaś wydatki Europejskiego Funduszu Rolnego na rzecz Rozwoju Obszarów Wiejskich mają być aż o 17\% niższe. Kluczowym elementem wsparcia mają pozostać płatności bezpośrednie, a realizowane działania mają być jeszcze bardziej ukierunkowane na kwestie środowiskowe. Propozycje KE co do podziału środków na lata 2021-2027 oznaczają iż udział wydatków na WPR i rybołówstwo spadnie do $28,5 \%$ i będzie zbliżony do udziału środków przeznaczonych na spójność gospodarczą, społeczną i terytorialną, a największy udział w budżecie będą miały wydatki na inne programy. Oznacza to istotną zmianę w strukturze wydatków i odzwierciedla nowe priorytety UE.

Tabela 1. Budżet WPR 2021-2027 (ceny bieżące; euro)

\begin{tabular}{|lcccr|}
\hline \multicolumn{1}{|c}{ Wyróżnienie } & $\begin{array}{c}\text { A. UE-28 } \\
\mathbf{2 0 1 4 / 2 0 2 0}\end{array}$ & $\begin{array}{c}\text { B. UE-27 } \\
\mathbf{2 0 1 4 / 2 0 2 0}\end{array}$ & \multicolumn{1}{c|}{$\begin{array}{c}\text { C. UE-27 } \\
\mathbf{2 0 2 1 / 2 0 2 7}\end{array}$} & Zmiana B/C w \% \\
\hline 1. EFRG & 302797 & 280351 & 286195 & $-17 \%$ \\
2. EFRROW & 100273 & 95078 & 78811 & $-3 \%$ \\
& 403070 & 375429 & 365005 & $20 \%$ \\
3. WPR łącznie & 1115919 & 1063101 & 1279408 & -- \\
4. Lącznie WRF & $36.1 \%$ & $35.3 \%$ & $28.5 \%$ & \\
5. \% WPR (3/4) & & & & \\
\hline
\end{tabular}

Źródło: B. Wieliczko: Planowany kształt WPR 2021-2027 a globalizacja i integracja, referat wygłoszony podczas IV Konferencji Naukowej pt. „Aktualne tendencje w międzynarodowych stosunkach gospodarczych” zorganizowanej przez SGGW, Kociszew 11.10.2018.

\section{Instrumenty finansowe - dylematy definicyjne i klasyfikacyjne}

Historycznie rzecz biorąc, instrumenty finansowe wyprowadzić można z ogólnych instrumentów ekonomicznych i rodzajów transakcji handlowych, typu: ceny, kursy czy podatki wraz z mechanizmami ich ustalania, produkty bankowe i reguły ich wyceny czy produkty będące przedmiotem obrotu na różnych giełdach i platformach obrotu. Współcześnie jednak przez powyższe instrumenty rozumie się kontrakty pieniężne, dokumentujące jakiś tytuł własności albo prawo dostarczenia lub otrzymania wartości pieniężnych. W tym znaczeniu wyróżnia się instrumenty:

1. Pieniężne, które wycenia się bezpośrednio na rynku. Mogą być to papiery wartościowe, pożyczki/kredyty lub depozyty.

2. Pochodne, gdzie ich wartość wynika z cen jakiś innych aktywów, indeksów, stóp procentowych albo ich kombinacji.

Z kolei Międzynarodowe Standardy Rachunkowości (IAS) 32 i 39 instrumenty finansowe definiują jako kontrakty, które generują powstanie jakiegoś aktywu, zobowią- 
zania lub udziału w kapitale własnym podmiotu gospodarczego ${ }^{5}$. Z kolei, z perspektywy polskiego prawa bilansowego, termin ,instrumenty finansowe”, o relatywnie szerokim zakresie, obejmuje „kontrakty, w wyniku których u jednej ze stron powstają aktywa finansowe, a u drugiej zobowiazzania finansowe lub instrumenty kapitałowe ${ }^{6}$.

Rosnące zainteresowanie instytucji ogólnounijnych instrumentami finansowymi wynika z niskiej efektywności tradycyjnych subsydiów oraz istnienia znanych niedoskonałości rynków finansowych, których pierwotnym źródłem jest asymetria informacji stron rozważających zawarcie kontraktu na ich dostarczenie. Jej pochodnymi są negatywna selekcja oraz hazard moralny, nazywany w Polsce często pokusą nadużycia. W ślad za tym podmioty gospodarcze mogą spotkać się z zewnętrznymi ograniczeniami kredytowymi/finansowymi, których częstym wyrazem jest racjonowanie kredytu, pojawienie się luki finansowej i nieoptymalnych inwestycji. Sporo rynków finansowych jest przy tym równocześnie niekompletnymi, a więc brakuje na nich wszystkich produktów niezbędnych do funkcjonowania i rozwoju współczesnych firm. Na negatywne następstwa niedoskonałości i niekompletności rynków finansowych szczególnie narażony jest sektor małych i średnich przedsiębiorstw (MSP) oraz tzw. startupy ${ }^{7}$. W takich to warunkach instytucje ogólno-unijne doszły po ostatnim kryzysie do wniosku, by zacząć interweniować na rynkach finansowych, ale równocześnie $\mathrm{w}$ minimalnym stopniu angażować szczupłe zasoby budżetowe Wspólnoty. Stwierdzono, że najlepszą strategią będzie kurs na inżynierię finansową i łączenie/partnerstwo kapitałów prywatnych z publicznymi.

Instrumenty finansowe są wykorzystywane w polityce finansowej UE już od 1994 początkowo, w ramach funduszy strukturalnych ${ }^{8}$. Nowym elementem w latach 20142020 jest przyznanie poszczególnym krajom członkowskim dużej autonomii zarówno w zakresie planowania programów, jak również bardzo elastycznego dopasowania do nich odpowiedniego instrumentu finansowego. $\mathrm{W}$ procesie upowszechnienia i dystrybucji instrumentów finansowych zaangażowane zostały, co wynika naturalnie z ich funkcji, tzw. narodowe banki rozwoju (national development banks, NDBs). Przykładowo, nasz Bank Gospodarstwa Krajowego (BGK) wyodrębnił w swoim portfolio produktów następujące instrumenty pozadotacyjne':

- podstawowe instrumenty inżynierii finansowej (IIF) - instrumenty zwrotne: pożyczka; poręczenie; wejście kapitałowe (equity);

- pozostałe instrumenty pozadotacyjne: umorzenie lub spłata części kapitału kredytu/pożyczki; umorzenie lub spłata części odsetek kredytu/pożyczki (tzw. dofinansowanie odsetek od kredytów).

\footnotetext{
${ }^{5}$ IFRS Foundation, 2017, List of Standards. http://www.ifrs.org/issued-standards/list-of-standards/, dostep z dnia 10.05.2017.

${ }^{6}$ Art. 3 ust. 1 pkt 23 ustawy o rachunkowości; Dz. U. z 1994 r. nr 121, poz. 591.

${ }^{7}$ J. Jędrzejczak-Gas: Samofinansowanie przedsiębiorstw, Ekonomika i Organizacja Przedsiębiorstw, nr 2(697), 2008, s. 69-74.

${ }^{8}$ W. Wishlade, R. Michie: Financial instruments in 2014-20: learning from 2007-13 and adapting to the new environment, "Challenges for the New Cohesion Policy 2014-20: an Academic and Policy Debate", 2 nd joint EU Cohesion Policy conference, Riga, 4-6 February 2014.

${ }^{9}$ BGK: Zarządzanie instrumentami pozadotacyjnymi UE - doświadczenia BGK (prezentacja online) Łódź, 24.05.2012. https://www.mos.gov.p1/g2/big/2012_06/313bfcbd60caef8281fb41b94b5cf35e.ppt, dostęp z dnia 1.07.2017.
} 
W tabeli 1 przedstawiono wady i zalety związane ze stosowaniem najbardziej kluczowych instrumenty finansowych, które mogą być wykorzystywane do realizacji celów założonych w polityce spójności. Warto wspomnieć o mikrokredytach, które mogą być przeznaczone „na zakup sprzętu, aby poprawić wartość dodaną i jakość zbiorów, lub dla wsparcia projektów w ramach strategii rozwoju kierowanego przez społeczność lokalną"10.

Tabela 1. Instrumenty finansowe wykorzystywane w polityce spójności - zalety i wady

\begin{tabular}{|c|c|c|}
\hline Instrument & Wady & Zalety \\
\hline $\begin{array}{l}\text { Gwarancje } \\
\text { kredytowe }\end{array}$ & $\begin{array}{l}\text { - Trudności w osiagnię- } \\
\text { ciu efektu „,zachęty” } \\
\text { - Kontrola zobowiązań w } \\
\text { przypadku problemów } \\
\text { z gwarancjami }\end{array}$ & $\begin{array}{l}\text { - Zintegrowanie struktury finansowej dużej liczby projek- } \\
\text { tów nawet przy znacznych ograniczeniach finansowych } \\
\text { - Podstawa zmniejszenie premii za ryzyka w przypadku } \\
\text { dalszego finansowania } \\
\text { - Specyficzne ograniczenia możliwości akceptacji ryzyka } \\
\text { dla danego segmentu rynku }\end{array}$ \\
\hline Pożyczki & $\begin{array}{l}\text { Potrzebne jest znacznie } \\
\text { większe wsparcie, } \\
\text { szczególnie w fazie } \\
\text { rozruchu funduszu po- } \\
\text { życzkowego }\end{array}$ & $\begin{array}{l}\text { - Reakcja na ograniczenia płynności, a także akceptacja } \\
\text { ryzyka w segmencie rynkowym } \\
\text { - Wykorzystanie efektu rewolwingowego }\end{array}$ \\
\hline $\begin{array}{l}\text { Fundusze } \\
\text { kapitałowe i } \\
\text { venture }\end{array}$ & $\begin{array}{l}\text { Znaczny poziom ryzyka } \\
\text { ponoszonego przez po- } \\
\text { średników finansowych }\end{array}$ & $\begin{array}{l}\text { - Współuczestnictwo w zarządzaniu projektami i dostęp do } \\
\text { informacji o decydentach }\end{array}$ \\
\hline $\begin{array}{l}\text { Mezzanine } \\
\text { (fundusze } \\
\text { quasi- } \\
\text { kapitałowe, } \\
\text { quasi-equity) }\end{array}$ & $\begin{array}{l}\text { Zbyt wysokie koszty } \\
\text { transakcyjne, wynika- } \\
\text { jące z relatywnie dużej } \\
\text { złożoności produktów } \\
\text { - } \\
\text { Znaczne ryzyko (choć } \\
\text { zredukowane w po- } \\
\text { równaniu do fundu- } \\
\text { szów kapitałowych) } \\
\end{array}$ & $\begin{array}{l}\text { - Mitygacja ryzyka straty w przypadku sytuacji niewypła- } \\
\text { calności } \\
\text { - Pokrycie luki kapitałowej, niezbędnej do pozyskania } \\
\text { dodatkowych pożyczek }\end{array}$ \\
\hline
\end{tabular}

Źródło: opracowanie własne na podstawie: Ecorys, 2016, Ocena ex ante celowości zastosowania instrumentów finansowych w ramach Programu Rozwoju Obszarów Wiejskich na lata 2014-2020. Raport dla MRiRW. Warszawa, 30.11.2016. http://www.minrol.gov.pl/Ministerstwo/Biuro-Prasowe/Informacje-Prasowe/Ocena-exante-celowosci-zastosowania-instrumentow-finansowych-w-ramach-PROW-2014-2020, dostęp z dnia 1.07.2017; EIPA-Ecorys-PwC, 2014, Financial instruments in Cohesion Policy, 2014-2020: Ex-ante assessments. Managing Authority training, June 2014 (for European Commission and European Investment Bank). http://ec.europa.eu/regional_policy/sources/thefunds/fin_inst/pdf/ex_ante_training.pdf, dostęp z dnia 1.07.2017.

Instrumenty finansowe, które do 2014 roku były zwane instrumentami inżynierii finansowej, są coraz powszechniej stosowane w unijnej polityce wsparcia rozwoju poszczególnych regionów i sektorów gospodarki Unii Europejskiej. Obecnie występują dwa typy zarządzania instrumentami finansowymi:

- zarządzanie centralne, w ramach którego Komisja Europejska jest bezpośrednio zaangażowana $\mathrm{w}$ projektowanie i strategię inwestycyjną. Instrumenty te dotyczą

\footnotetext{
${ }^{10}$ Europejski Bank Inwestycyjny, 2015, Europejski Fundusz Rolny na rzecz Rozwoju Obszarów Wiejskich. Instrumenty finansowe. Europejski Bank Inwestycyjny, Luksemburg.
} 
różnych obszarów aktywności UE, w tym m.in. badań, edukacji, kultury i przemysłu.

- zarządzanie dzielone między KE i państwa członkowskie realizowane w ramach poszczególnych funduszy tworzących unijną politykę spójności, w tym także Europejski Fundusz Rolny na rzecz Rozwoju Obszarów Wiejskich (EFRROW).

W okresie programowania 2007-2013 stosowanie instrumentów finansowych w ramach programów współfinansowanych ze środków Europejskiego Funduszu Rozwoju Regionalnego (EFRR) i Europejskiego Funduszu Społecznego (EFS) było niemal powszechne. Instrumenty te stosowało 25 państw członkowskich w ramach EFRR, a w EFS jedynie siedem ${ }^{11}$. W sumie ze środków EFRR realizowano 972 instrumenty finansowe, a z funduszy EFS jedynie $53^{12}$. Jednakże poziom finansowania tych instrumentów wydaje się niewielki na tle łącznego budżetu wdrażanych programów. Do końca 2014 roku realizowane instrumenty finansowe wsparto łączną kwotą 16 mld euro ${ }^{13}$ (środki EFRR i EFS $)^{14}$. Niemniej jednak oznacza to ponad dwunastokrotny wzrost w stosunku do okresu programowania 2000-2006, kiedy na instrumenty finansowe wydatkowano jedynie 1,3 mld euro z budżetu UE w ramach obu funduszy, a w okresie 1994-1999 tylko 0,6 mld euro ${ }^{15}$. Dodatkowo, w okresie 2007-2013 na 21 instrumentów finansowych bezpośrednio wdrażanych przez Komisję Europejską wydatkowano 5,5 mld euro ${ }^{16}$.

Twórcy wielu programów współfinansowanych ze środków UE przeszacowali popyt na instrumenty finansowe, w wyniku czego na koniec 2014 roku wykorzystano średnio $57 \%$ kapitału przeznaczonego na te działania w ramach programów operacyjnych. Co szczególnie istotne, instrumenty finansowe nie przyciagnęły kapitału prywatnego. Udział środków prywatnych w łącznym budżecie instrumentów finansowych w latach realizowanych przy współudziale środków EFRR i EFS szacowany jest na ok. $2 \%{ }^{17}$. Dodatkowo opóźnienia w uruchamianiu instrumentów sprawiły, iż w większości z nich zwrócone przez beneficjenta środki nie mogły już być ponownie wykorzystane, co wynikało z przeciagającego się procesu przygotowania regulacji i procedur funkcjonowania wsparcia oraz negocjacji z pośrednikami finansowanymi. W związku z tym nie wystapiła na znaczną skalę jedna $\mathrm{z}$ ważnych zalet stosowania instrumentów finansowych, czyli ich odnawialny charakter.

Ponadto, istotnym problemem jest kwestia kosztów funkcjonowania instrumentów finansowych. Nie chodzi tu oczywiście jedynie o fakt, iż w przypadku 2,2\% instrumentów realizowanych w okresie programowania 2007-2013 ze współfinansowaniem środków z EFRR lub EFS łączne koszty zarządzania przekroczyły kwotę przekazaną końcowym beneficjentom ${ }^{18}$. Łączne koszty administracji i zarządzania funduszami w więk-

\footnotetext{
${ }^{11}$ European Court of Auditors, 2016, Implementing the EU budget through financial instruments - lessons to be learnt from the 2007-2013 programme period. Special Report no. 19/2016. Luxembourg: European Court of Auditors.

${ }^{12}$ Ibidem

${ }^{13}$ Dla porównania środki EFRROW w okresie 2014-2020 to 96 mld euro; $12 . \quad$ Europejski Bank Inwestycyjny: Europejski Fundusz Rolny na rzecz Rozwoju Obszarów Wiejskich. Instrumenty finansowe. Europejski Bank Inwestycyjny, Luksemburg, 2015.

${ }^{14}$ European Court of Auditors, 2016, Implementing the EU budget... op. cit.

${ }^{15}$ Ibidem

${ }^{16}$ Ibidem

${ }^{17}$ Ibidem

${ }^{18}$ Ibidem
} 
szości państw wdrażających instrumenty finansowe sięgnęły co najmniej $10 \%$ kwoty przekazanej końcowym beneficjentom, a ich najwyższy poziom odnotowano na Słowacji - 75\% środków wypłaconych ostatecznym odbiorcom i w Czechach - 47\%, zaś w Polsce wyniosły one $10 \%{ }^{19}$. W związku z wysokim poziomem kosztów funkcjonowania instrumentów finansowych w okresie programowania 2014-2020 wprowadzono dodatkowe regulacje mające na celu ich ograniczenie, wprowadzając określone pułapy i limity uzależnione od typu instrumentu. Należy jednocześnie dodać, iż pewne ograniczenia obowiazzywały już w poprzednim okresie programowania, a obecne pułapy kosztów są niższe niż poprzednio ${ }^{20}$.

Doświadczenia we wdrażaniu instrumentów finansowych w kolejnych okresach programowania stanowią istotny wkład w przygotowanie nowych rozwiązań prawnych ich funkcjonowania w kolejnych latach. Nadal jednak wykorzystywanie instrumentów finansowych nie jest popularne. Obecnie, poza samym rozpowszechnieniem korzystania z tych instrumentów, kluczowym wyzwaniem jest optymalizacja wielkości środków przeznaczonych na ten cel. Jest to jednocześnie zadanie niezwykle trudne, co pokazują wyniki badania przeprowadzonego przez Europejski Trybunał Obrachunkowy wśród zarządzających największymi funduszami oferującymi instrumenty finansowe współfinansowane ze środków EFRR, które wskazują, że wykorzystanie przeznaczonych na te działania środków w okresie programowania 2007-2013 w 26\% badanych podmiotów sięgało $0-30 \%$ środków, zaś jedynie $12 \%$ funduszy w pełni wykorzystano zaplanowany budżet ${ }^{21}$. Oszacowanie wielkości popytu na instrumenty finansowe zależy nie tylko od warunków udzielania wsparcia, ale także m.in. od alternatywnych dla potencjalnych beneficjentów rozwiązań w zakresie pozyskiwania środków na inwestycje oraz od ogólnej koniunktury gospodarczej. W związku z tym, iż we wcześniejszych okresach programowania często brakowało niezależnej oceny wielkości luki finansowej ${ }^{22}$, co zresztą nie było wymagane ${ }^{23}$, w okresie 2014-2020 wprowadzono obowiazzek przeprowadzenia szczegółowej oceny ex-ante, jednak nadal nie jest wymagane przeprowadzenie jej niezależnej oceny. To wciąż może prowadzić do przeszacowania wielkości ww. luki, a co za tym idzie także wielkości popytu na wsparcie.

\section{Fundusz Junckera jako przykład inżynierii finansowej}

Niekiedy przez inżynierię finansową uznaje się nawet dostosowanie oferty kredytowej banków do potrzeb konkretnego podmiotu gospodarczego lub osoby fizycznej. Trudno jednak zaakceptować takie ujęcie. Bez porównania lepiej sens tego pojęcia oddaje definicja, w której rozumie się ją jako wykorzystywanie metod statystycznych i ekonometrycznych oraz matematyki finansowej do zarządzania ryzykiem przy zastosowaniu instrumentów finansowych i giełd papierów wartościowych. Współcześnie jednak dominuje znacznie szersza perspektywa. Zgodnie z nią inżynieria finansowa to integracja wielu dyscyplin, a więc teorii finansów, nauk inżynierskich, matematyki, informatyki,

\footnotetext{
${ }^{19}$ Ibidem

${ }^{20}$ Ibidem

${ }^{21}$ Ibidem

${ }^{22}$ European Court of Auditors, 2012, Financial Instruments for SMEs Co-Financed by the European Regional Development Fund. Special Report no. 2/2012. Luxembourg: European Court of Auditors.

${ }^{23}$ European Court of Auditors, 2016, Implementing the EU budget... op. cit.
} 
ekonometrii i rozmaitych technik programowania, która ma pozwolić przygotować nowe produkty i strategie finansowe, w tym dotyczące zarządzania ryzykiem, przy jednoczesnym przestrzeganiu obowiązujących regulacji. W ujęciu bardziej zdezagregowanym obszarami zastosowań powyższej inżynierii są: finanse korporacyjne, wycena derywatów i opcji, konstruowanie produktów strukturyzowanych, zarządzanie portfelem i ryzykiem. Trzeba od razu dodać, że inżynieria finansowa jest przedmiotem różnorakiej krytyki, która szczególnie nasiliła się po kryzysie z lat 2007-2008. Przede wszystkim zarzuca się jej nieprzejrzystość, oderwanie od realiów gospodarki oraz tworzenie nowych rodzajów ryzyka i propagację szoków w skali globalnej.

Stopniowe wdrażanie „Planu inwestycyjnego dla Europy”, określonego powszechnie jako tzw. Fundusz Junckera, będącego „odpowiedzią” KE na wyzwania stojące przed rozwojem UE, dotkniętej przez kryzys finansowy, fiskalny i ekonomiczny, ma zapewnić wzrost inwestycji, a co za tym idzie ożywienie gospodarcze i wzrost konkurencyjności wspólnotowej gospodarki. Komisja Europejska przedstawiła w listopadzie 2014 r. swój komunikat na ten temat (dokument $\operatorname{COM}(2014) 903)^{24}$. Plan inwestycyjny opiera się na trzech kluczowych „filarach”: (1) uruchomienie/aktywacja środków finansowych na inwestycje, (2) zasilanie gospodarki realnej środkami finansowymi oraz poprawa otoczenia inwestycyjnego (rys. 1).

\footnotetext{
${ }^{24}$ Komisja Europejska, 2014, Komunikat Komisji do Parlamentu Europejskiego, Rady, Europejskiego Banku Centralnego, Europejskiego Komitetu Ekonomiczno-Społecznego, Komitetu Regionów oraz Europejskiego Banku Inwestycyjnego, Plan inwestycyjny dla Europy. COM(2014)903. http://data.consilium.europa.eu/doc/document/ST-16115-2014-INIT/pl/pdf, dostęp z dnia 1.07.2017.
} 


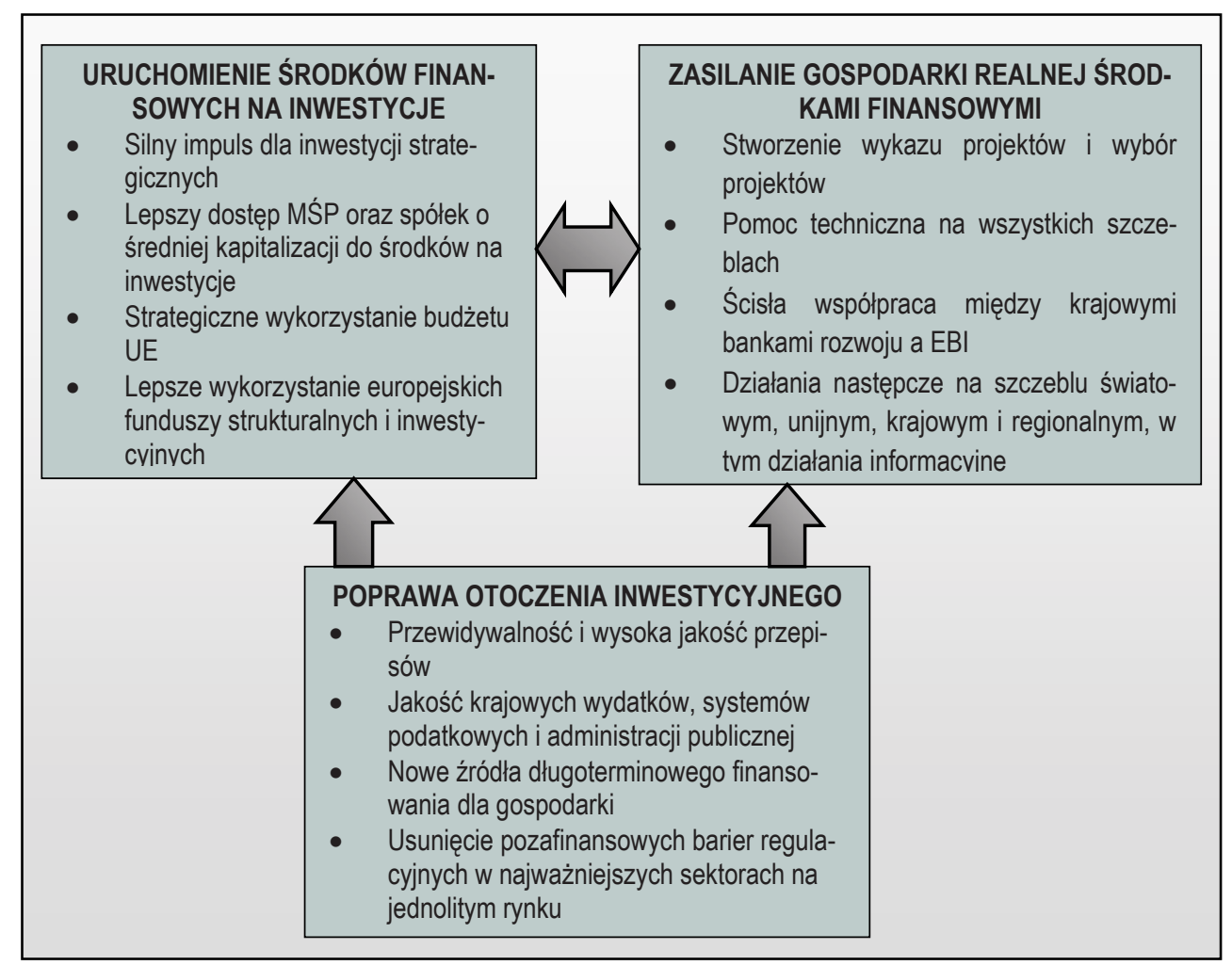

Rysunek 1. Trzy kluczowe elementy „Planu inwestycyjnego dla Europy”

Źródło: Komisja Europejska, Komunikat Komisji do Parlamentu Europejskiego, Rady, Europejskiego Banku Centralnego, Europejskiego Komitetu Ekonomiczno-Społecznego, Komitetu Regionów oraz Europejskiego Banku Inwestycyjnego, Plan inwestycyjny dla Europy. COM(2014)903 ..., s. 5.

Europejski Fundusz na Rzecz Inwestycji Strategicznych (EFIS) jest głównym narzędziem realizacji „Planu inwestycyjnego...”. Służy on wsparciu inwestycji o charakterze strategicznym dla EU, a zwłaszcza inwestycji infrastrukturalnych. Jednocześnie jednak ma pomagać wspieraniu MŚP i spółkom o średniej kapitalizacji. Fundusz ten został utworzony wspólnie przez KE i Europejski Bank Inwestycyjny (EBI). Szacowany efekt mnożnikowy ma wynieść 15 , tj. zaangażowanie przez KE 16 mld euro oraz 5 mld euro przez EBI powinno przynieść 315 mld euro w postaci inwestycji w gospodarkę. Zasady funkcjonowania EFIS określa rozporządzenie (UE) 2015/101725.

Na oczekiwany efekt mnożnikowy wynoszący 15 składa się iloczyn zwiększenia zdolności do ponoszenia ryzyka oraz zaangażowanie innych inwestorów (rys. 2). Dzięki zwiększeniu zdolności do ponoszenia ryzyka 1 euro środków w EFIS ma przynieść 3 razy tyle nakładów inwestycyjnych. Zwiększy to zdolność EFIS do 3 euro z każdego

${ }^{25}$ Komisja Europejska, 2015, Plan inwestycyjny dla Europy - pytania i odpowiedzi. Bruksela, 20 lipca 2015. http://europa.eu/rapid/press-release_MEMO-15-5419_pl.pdf, dostęp z dnia 1.07.2017. 
zainwestowanego przez UE i EBI euro. Środki te natomiast zostaną pomnożone pięciokrotnie dzięki włączeniu innych inwestorów. Tym samym łączny efekt mnożnikowy zainwestowanych w EFIS środków wyniesie ww. $15^{26}$.

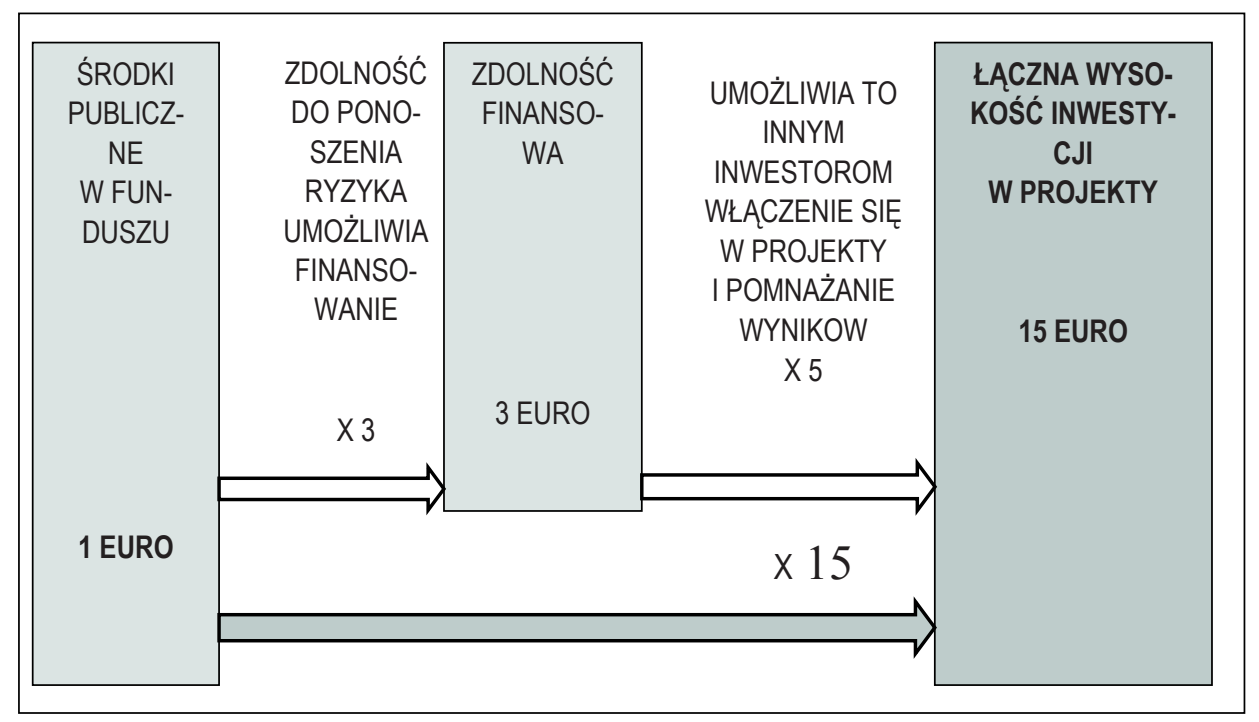

Rysunek 2. Oczekiwany efekt mnożnikowy EFIS

Źródło: jak do rysunku poprzedniego, s. 9.

W ramach EFIS UE udziela EBI gwarancji pozwalających na stosowanie szerokiej gamy produktów finansowych obejmujących następujące instrumenty (rozporządzenie 2015/1017 art. 10 ust. 2):

- pożyczki EBI, gwarancje, kontrgwarancje, instrumenty rynku kapitałowego, wszelkie inne formy finansowania lub instrumenty wsparcia zdolności kredytowej, udziały kapitałowe i quasi-kapitałowe, w tym na rzecz krajowych banków lub instytucji prorozwojowych, platform lub funduszy inwestycyjnych;

- finansowanie lub gwarancje zapewniane przez EBI na rzecz EFI, umożliwiające temu drugiemu udzielanie pożyczek, gwarancji, kontrgwarancji, wszelkich innych form instrumentów wspierających zdolność kredytową, instrumentów rynku kapitałowego i udziałów kapitałowych lub quasi-kapitałowych, w tym na rzecz krajowych banków lub instytucji prorozwojowych, platform lub funduszy inwestycyjnych;

- gwarancje EBI udzielane krajowym bankom lub instytucjom prorozwojowym, platformom lub funduszom inwestycyjnym w ramach gwarancji $\mathrm{UE}^{27}$.

\footnotetext{
${ }^{26}$ Ibidem.

${ }^{27}$ Rozporządzenie Parlamentu Europejskiego i Rady (UE) 2015/1017 z dnia 25 czerwca 2015 r. w sprawie Europejskiego Funduszu na rzecz Inwestycji Strategicznych, Europejskiego Centrum Doradztwa Inwestycyjnego i Europejskiego Portalu Projektów Inwestycyjnych oraz zmieniającego rozporządzenia (UE) nr 1291/2013 i (UE) nr 1316/2013 - Europejski Fundusz na rzecz Inwestycji Strategicznych, (Dz.U. UE L 169).
} 
Rozporządzenie (UE) 2015/1017 dotyczy również Europejskiego Centrum Doradztwa Inwestycyjnego (ECDI) i Europejskiego Portalu Projektów Inwestycyjnych, czyli pozostałych narzędzi realizacji „Planu Inwestycyjnego dla Europy”. Zadaniem ECDI jest „rozbudowa istniejących struktur doradczych EBI i Komisji w celu udzielania wsparcia doradczego w zakresie identyfikowania projektów inwestycyjnych, ich przygotowania i rozwijania oraz pełnienia funkcji pojedynczego kompleksowego centrum doradztwa technicznego w dziedzinie finansowania projektów w Unii" (Art. 14 Rozporządzenia (UE) 2015/1017). Wsparcie doradcze ma charakter zarówno prawny, jak i techniczny. Odnosi się ono do pomocy w konstruowaniu projektów, wykorzystaniu do ich finansowania innowacyjnych instrumentów finansowych i tworzenia partnerstw publicznoprywatnych $^{28}$.

Usługi świadczone przez ECDI generalnie są płatne. Jednakże w przypadku podmiotów sektora MŚP opłaty nie mogą przekraczać 1/3 kosztów usług doradczych, a usługi stanowiące uzupełnienie usług realizowanych $\mathrm{w}$ ramach programów unijnych udzielane publicznym promotorom projektów nie podlegają opłacie. UE na realizację usług ECDI przeznaczyła 20 mln euro (łącznie do końca 2020 r.).

Ostatnie z narzędzi „Planu inwestycyjnego dla Europy” to Europejski portal projektów inwestycyjnych (EPPI). Portal ten zawiera wykaz obecnie realizowanych i przyszłych projektów w Unii. Publicznie dostępny i łatwy w obsłudze portal ma służyć celom informacyjnym.

W budżecie UE na lata 2021-2027 KE zaproponowała, aby powołać fundusz InvestEU, który ma wchłonąć wszystkie dotychczasowe centralnie zarządzane instrumenty finansowe. Planowany poziom środków na rzecz tego funduszu to 15,2 mld euro. Środki te mają wygenerować inwestycje o łącznej wartości $650 \mathrm{mld}$ euro ${ }^{29}$.

\section{Podsumowanie i wnioski}

Niedoskonałości i niekompletności rynków finansowych, a kredytu w szczególności, mogą stanowić uzasadnienie dla rozważnej interwencji publicznej. W ten sposób można próbować łagodzić ograniczenia kredytowe i finansowe, szczególnie mocno dotykające małe i średnie firmy, stymulować inwestycje i innowacje oraz poprawiać zarządzanie ryzykiem. Rozległy i niejako ponadczasowy interwencjonizm finansowy i kredytowy w dłuższym okresie może jednakże doprowadzić do osłabienia bodźców do wzrostu efektywności i produktywności. Szczególne niebezpieczeństwo pojawia się wtedy, gdy interwencja publiczna zdominowana jest przez dotacje i subwencje. Wykształca się wówczas swoista kultura dotacyjna, wyrażająca się m.in. w pogoni za rentami politycznymi i ekonomicznymi zamiast koncentracji na tworzeniu solidnych ram prowadzenia działalności gospodarczej. W przypadku UE poleganie na wsparciu dotacyjnym dotyczy głównie WPR oraz polityki spójności, które obecnie stanowią 70\% wydatków Wspólnoty. W tym kontekście instrumenty finansowe powinny w coraz większym stopniu stawać się substytutami subsydiów. Szeroki pakiet zróżnicowanych instrumentów finansowych, chociaż wcale nie pozbawiony pewnych niedoskonałości

\footnotetext{
${ }^{28}$ Ibidem.

${ }^{29}$ European Commission, EU budget for the future. Investments, https://ec.europa.eu/commission/sites/betapolitical/files/budget-proposals-investments-may2018_en.pdf, 2018.
} 
zarówno z punktu widzenia instytucji finansowej, jak i przedsiębiorstwa, będzie stopniowo wypierał dotychczas stosowane formy wsparcia dotacyjnego. Przesłanką za wykorzystaniem, a najpierw jednak skutecznym rozpowszechnieniem, nowoczesnych sposobów finansowania jest przede wszystkim dążenie do poprawy dostępu do kapitału dla szerokiego grona podmiotów z sektora MŚP ${ }^{30}$. Nie będzie to jednak łatwy i szybki proces, co znajdzie wyraz w ostrości negocjacji budżetu Wspólnoty na lata 2020+ oraz w jego finalnym kształcie.

\section{Bibliografia}

BGK, Zarządzanie instrumentami pozadotacyjnymi UE - doświadczenia BGK (prezentacja online) Łódź, 24.05.2012.

https://www.mos.gov.pl/g2/big/2012_06/313bfcbd60caef8281fb41b94b5cf35e.ppt, dostęp z dnia 1.07.2017.

Dec P., Masiukiewicz P.: The Support System for Small and Medium Business: Case of Poland, Research in World Economy, Vol. 5 (2014), Iss. 2 (September), 2014, ss. 150-158.

Ecorys: Ocena ex ante celowości zastosowania instrumentów finansowych w ramach Programu Rozwoju Obszarów Wiejskich na lata 2014-2020. Raport dla MRiRW. Warszawa, 2016,

30.11.2016. http://www.minrol.gov.pl/Ministerstwo/Biuro-Prasowe/Informacje-Prasowe/Ocenaex-ante-celowosci-zastosowania-instrumentow-finansowych-w-ramach-PROW-2014-2020, dostęp $\mathrm{z}$ dnia 1.07.2017.

EIPA-Ecorys-PwC: Financial instruments in Cohesion Policy, 2014-2020: Ex-ante assessments. Managing Authority training, June 2014 (for European Commission and European Investment Bank). http://ec.europa.eu/regional_policy/sources/thefunds/fin_inst/pdf/ex_ante_training.pdf, dostęp z dnia 1.07.2017.

European Commission: EU budget for the future. Investments,

https://ec.europa.eu/commission/sites/beta-political/files/budget-proposals-investmentsmay2018_en.pdf, 2018.

European Commission: European Structural and Investment Funds and European Fund for Strategic Investments complementarities Ensuring Coordination, Synergies And Complementarity February 2016.

http://ec.europa.eu/regional_policy/sources/thefunds/fin_inst/pdf/efsi_esif_compl_en.pdf, dostęp z dnia 1.07.2017.

European Commission: White Paper on the Future o Europe. Reflections and scenarios for the EU27 by 2025. Brussels, 1.03.2017, https://ec.europa.eu/commission/sites/betapolitical/files/white_paper_on the future_of_europe_en.pdf, dostęp z dnia 1.07.2017.

European Court of Auditors: Are financial instruments a successful and promising tool in the rural development area? Special report No. 5/2015. Luxembourg: European Court of Auditors.

European Court of Auditors: Financial Instruments for SMEs Co-Financed by the European Regional Development Fund. Special Report no. 2/2012. Luxembourg: European Court of Auditors. European Court of Auditors: Implementing the EU budget through financial instruments - lessons to be learnt from the 2007-2013 programme period. Special Report no. 19/2016. Luxembourg: European Court of Auditors.

${ }^{30}$ B. Lepczyński, M. Penczar: Znaczenie instrumentów zwrotnych w ograniczaniu luki finansowej i podnoszeniu bezpieczeństwa finansowego przedsiębiorstw z sektora MSP, Zarządzanie i Finanse, t. 4, nr 4, 2013, s. 83-99; P. Dec, P. Masiukiewicz, The Support System for Small and Medium Business: Case of Poland, Research in World Economy, Vol. 5 (2014), Iss. 2 (September), 2014, ss. 150-158. 
European Investment Bank: 2016 EFSI Report. From the European Investment Bank to the European Parliament and the Council on 2016 EIB Group Financing and Investment Operations under EFSI, European Investment Bank, Luxembourg.

Europejski Bank Inwestycyjny: Europejski Fundusz Rolny na rzecz Rozwoju Obszarów Wiejskich. Instrumenty finansowe. Europejski Bank Inwestycyjny, Luksemburg, 2015.

IFRS Foundation: List of Standards, 2017 http://www.ifrs.org/issued-standards/list-of-standards/, dostęp z dnia 10.05.2017.

Jędrzejczak-Gas, J.: Samofinansowanie przedsiębiorstw, Ekonomika i Organizacja Przedsiębiorstw, nr 2(697), 2008, s. 69-74.

Komisja Europejska, 2016, Wniosek. Rozporządzenie Parlamentu Europejskiego i Rady zmieniające rozporządzenia (UE) nr 1316/2013 oraz (UE) 2015/1017 w odniesieniu do przedłużenia okresu obowiązywania Europejskiego Funduszu na rzecz Inwestycji Strategicznych oraz wprowadzenia usprawnień technicznych dla tego Funduszu oraz Europejskiego Centrum Doradztwa Inwestycyjnego, $\operatorname{COM}(2016) 597$.

Komisja Europejska: Komunikat Komisji i Parlamentu Europejskiego, Rady Europejskiej, Rady, Europejskiego Komitetu Ekonomicznospołecznego i Komitetu Regionów, Nowoczesny budżet dla Unii, która chroni, wspiera i broni. Wieloletnie ramy finansowe na lata 2021-2027,

COM(2018)321, 2018.

Komisja Europejska: Plan inwestycyjny dla Europy - pytania i odpowiedzi. Bruksela, 20 lipca 2015. http://europa.eu/rapid/press-release_MEMO-15-5419_pl.pdf, dostęp z dnia 1.07.2017. Komunikat Komisji do Parlamentu Europejskiego, Rady, Europejskiego Banku Centralnego, Europejskiego Komitetu Ekonomiczno-Społecznego, Komitetu Regionów oraz Europejskiego Banku Inwestycyjnego, Plan inwestycyjny dla Europy. COM(2014)903.

http://data.consilium.europa.eu/doc/document/ST-16115-2014-INIT/pl/pdf, 2014, dostęp z dnia 1.07.2017.

Komunikat Komisji do Parlamentu Europejskiego, Rady, Europejskiego Komitetu EkonomicznoSpołecznego, Komitetu Regionów oraz Europejskiego Banku Inwestycyjnego Czysta energia dla wszystkich Europejczyków, COM/2016/0860 final/2

Lepczyński B., Penczar M: Znaczenie instrumentów zwrotnych w ograniczaniu luki finansowej i podnoszeniu bezpieczeństwa finansowego przedsiębiorstw z sektora MSP, Zarządzanie i Finanse, t. 4, nr 4, 2013, s. 83-99.

Rozporządzenie delegowane Komisji (UE) 2015/1558 z dnia 22 lipca 2015 r. uzupełniające rozporządzenie Parlamentu Europejskiego i Rady (UE) 2015/1017 poprzez ustanowienie tabeli wskaźników do celów stosowania gwarancji UE, (Dz.U. UE L 244).

Rozporządzenie Parlamentu Europejskiego i Rady (UE) 2015/1017 z dnia 25 czerwca 2015 r. w sprawie Europejskiego Funduszu na rzecz Inwestycji Strategicznych, Europejskiego Centrum Doradztwa Inwestycyjnego i Europejskiego Portalu Projektów Inwestycyjnych oraz zmieniającego rozporządzenia (UE) nr 1291/2013 i (UE) nr 1316/2013 - Europejski Fundusz na rzecz Inwestycji Strategicznych, (Dz.U. UE L 169).

Ustawa o rachunkowości. Dz. U. z 1994 r. Nr 121, poz. 591.

Wieliczko B.: Planowany kształt WPR 2021-2027 a globalizacja i integracja, referat wygłoszony podczas IV Konferencji Naukowej pt. „Aktualne tendencje w międzynarodowych stosunkach gospodarczych" zorganizowanej przez SGGW, Kociszew 11.10.2018.

Wishlade, W., Michie, R.: Financial instruments in 2014-20: learning from 2007-13 and adapting to the new environment, "Challenges for the New Cohesion Policy 2014-20: an Academic and Policy Debate”, 2 nd joint EU Cohesion Policy conference, Riga, 4-6 February 2014. 


\section{Summary}

Opportunities for more efficient use of available fiscal revenues are currently being sought in EU. High hopes in this context are related to financial engineering and financial instruments. The main objective of the article is to present the essentials, benefits and risks, and areas of financial engineering and financial instruments. This paper is a review study. Documentary and literature review methods are employed. Extensive financial and credit interventions in the long run may, however, lead to a reduction in incentives for increased efficiency and productivity. Particular danger occurs when public intervention is dominated by subsidies. In the case of the EU, the reliance on subsidy support mainly concerns the CAP and cohesion policy, which currently account for $70 \%$ of EU spending. In this context, financial instruments, although not without defects, should increasingly become substitutes for subsidies. However, this will not be an easy and quick process, as will be reflected in the focus of the Community budget negotiations for $2020+$ and its final form.

Key words: financial instruments, cohesion policy, subsidies, EU budget, SME sector.

Informacja o autorach

\section{Dr Barbara Wieliczko}

Instytut Ekonomiki Rolnictwa i Gospodarki Żywnościowej-PIB, Zakład Finansów Rolnictwa,

ul. Świętokrzyska 20,

00-002 Warszawa

e-mail: Barbara.Wieliczko@ierigz.waw.pl

ORCID: https://orcid.org/0000-0003-3770-0409

Dr inż. Michal Soliwoda (autor korespondujący)

Instytut Ekonomiki Rolnictwa i Gospodarki Żywnościowej-PIB, Zakład Finansów Rolnictwa,

ul. Świętokrzyska 20,

00-002 Warszawa

e-mail: Michal.Soliwoda@ierigz.waw.pl

ORCID: https://orcid.org/0000-0003-4207-4641

Prof. dr hab. Jacek Kulawik

Instytut Ekonomiki Rolnictwa i Gospodarki Żywnościowej-PIB,

Zakład Finansów Rolnictwa,

ul. Świętokrzyska 20,

00-002 Warszawa

e-mail: Jacek.Kulawik@ierigz.waw.pl

ORCID: https://orcid.org/0000-0001-8731-1765 